\title{
Potensi Ekstrak Etanol dan Fraksi-Fraksinya dari Tiga Varietas Jahe sebagai Agen Antibakteri terhadap Staphylococcus aureus
}

\section{Potency of Ethanolic Extracts and Its Fractions of Three Ginger Varieties as Antibacterial Agent Against Staphylococcus aureus}

\author{
Dewi Dianasari*, Endah Puspitasari, Indah Yulia Ningsih, Bawon Triatmoko, Fauzia Ken Nastiti \\ Fakultas Farmasi, Universitas Jember, Jember, Indonesia \\ Email: dewi.dianasari@unej.ac.id
}

Received: 13 November 2019; Accepted: 7 Juni 2020; Published: 29 Juni 2020

\begin{abstract}
Abstrak
Salah satu bahan alam yang memiliki potensi untuk digunakan untuk menghambat pertumbuhan bakteri adalah rimpang jahe (Zingiber officinale). Di Indonesia sendiri, terdapat 3 jenis jahe yang dibedakan berdasarkan morfologinya, yaitu jahe emprit (Zingiber officinale var. Amarum), jahe gajah (Zingiber officinale var. Officinarum), dan jahe merah (Zingiber officinale var. Rubrum). Penelitian ini dilakukan untuk mengetahui aktivitas dari ekstrak dan fraksi dari tiga varietas jahe dalam menghambat pertumbuhan Staphylococcus aureus menggunakan metode difusi cakram. Kelompok uji terdiri dari ekstrak etanol, fraksi n-heksana, dan fraksi etil asetat dari 3 varietas jahe, konsentrasi 5, 10, $20 \%$ b/v, gentamisin $10 \mu \mathrm{g}$ (kontrol positif) dan DMSO 10\% (kontrol negatif). Hasil uji menunjukkan bahwa ekstrak etanol dan fraksi dari rimpang tiga varietas jahe memiliki daya hambat terhadap S.aureus pada konsentrasi 5,10 , dan $20 \%$ b/v, naiknya konsentrasi akan meningkatkan diameter zona hambatnya. Pada konsentrasi $20 \%$ dari semua sampel, yang memiliki daya hambat paling besar adalah fraksi n-heksana (diameter zona hambat jahe emprit $9,80 \mathrm{~mm}$, jahe gajah $9,78 \mathrm{~mm}$, dan jahe merah 9,90 mm). Perbedaan varietas jahe hanya mempengaruhi aktivitas antibakteri ekstrak etanol, tetapi tidak pada fraksi n-heksana dan etil asetat. Kata kunci: Antibakteri, jahe emprit, jahe gajah, jahe merah
\end{abstract}

\begin{abstract}
One of the natural ingredients that to be used to inhibit bacterial growth is the Zingiber officinale. In Indonesia, there are 3 types of ginger which are distinguished by morphology, namely 'emprit ginger (Zingiber officinale var. Amarum), ' gajah' ginger (Zingiber officinale var. Officinarum), and red ginger (Zingiber officinale var. Rubrum). This research was conducted to determine the activity of extracts and fractions of three ginger varieties in inhibiting the growth of Staphylococcus aureus using the disc diffusion method. The test group consisted of ethanol extract, $n$-hexane fraction, and ethyl acetate fraction from 3 ginger varieties, with the concentrations of $5,10,20 \% \mathrm{w} / \mathrm{v}$, gentamicin $10 \mu \mathrm{g}$ (positive control) and 10\% DMSO (negative control). The test results showed that ethanol extracts and fractions from the rhizomes of three varieties of ginger have the ability to inhibit S. aureus at concentrations of 5, 10, and 20\% w/v, increasing the concentration will increase the diameter of the inhibition zone. At a concentration of $20 \%$ of all samples, the one with the greatest resistance was the n-hexane fraction (diameter of inhibitory zone of emprit ginger $9.80 \mathrm{~mm}$, elephant ginger $9.78 \mathrm{~mm}$, and red ginger $9.90 \mathrm{~mm}$ ). The difference in ginger variety only affects the antibacterial activity of the ethanol extract, but not the $n$-hexane and ethyl acetate fractions.
\end{abstract}

Keywords: Antibacterial, 'emprit' ginger, 'gajah' ginger, red ginger

\section{PENDAHULUAN}

Penyakit infeksi merupakan salah satu penyakit dengan tingkat prevalensi yang tinggi, yang terjadi di seluruh dunia, dan juga di Indonesia (Rambiko et al., 2016). Penyakit infeksi dapat disebabkan oleh mikroorganisme patogen seperti bakteri, jamur, virus atau parasit. Bakteri Staphylococcus aureus menjadi salah satu penyebab penyakit infeksi. Beberapa penyakit yang diakibatkan oleh infeksi bakteri $S$. aureus yang banyak terjadi adalah infeksi kulit (Mishra et al., 2016). 


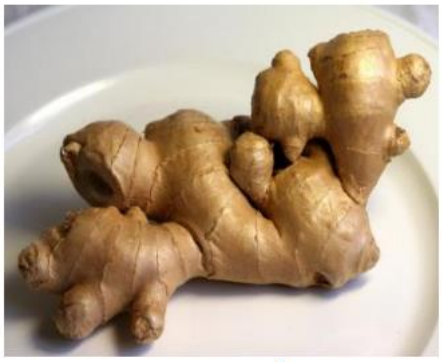

a)

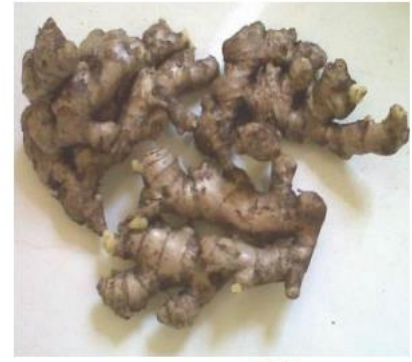

(b)

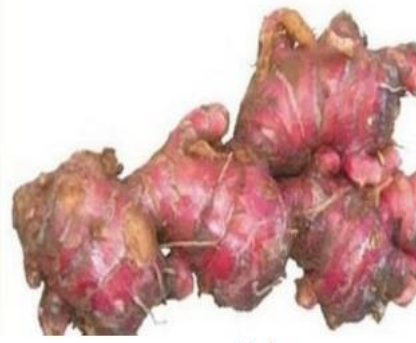

(c)

Gambar 1. Morfologi (a) jahe gajah, (b) jahe emprit, dan (c) jahe merah

Salah satu bahan alam yang memiliki potensi untuk menghambat pertumbuhan bakteri adalah rimpang jahe (Zingiber officinale). Di Indonesia ada 3 varietas jahe yang dapat dibedakan berdasarkan morfologinya, yaitu jahe emprit (Zingiber officinale var. Amarum), jahe gajah (Zingiber officinale var. Officinarum), dan jahe merah (Zingiber officinale var. Rubrum) (Setyawan et al., 2014). Perbedaan morfologi jahe terlihat pada Gambar 1.

Hasil uji yang dilakukan Sari dan Nasir, (2013) melaporkan bahwa ekstrak segar rimpang jahe memiliki aktivitas antimikroba terhadap bakteri $S$. aureus, Escherichia coli dan Candida albicans. Berdasarkan uraian di atas, maka dilakukan penelitian untuk mengetahui perbandingan aktivitas ekstrak tiga varietas rimpang jahe dan fraksi (n-heksana dan etil asetat) dari ketiga varietas rimpang jahe pada bakteri S.aureus.

\section{METODE PENELITIAN}

Alat

Alat yang

digunakan pada penelitian ini adalah Maserator, neraca (Ohaus), oven (Memmert), rotavapor (Heildolph), autoklaf (ALP), mikropipet (Socorex), LAF (Airtech), inkubator (Clifton), serta alat-alat gelas (Pyrex).

\section{Bahan}

Bahan sampel yang digunakan adalah rimpang jahe gajah (Zingiber officinale var. Officinarum), jahe emprit

(Zingiber officinale var. Amarum) dan jahe merah ((Zingiber officinale var. Rubrum) yang berasal dari Desa Kabuaran, Kabupaten Lumajang dan dideterminasi di Laboratorium Tanaman Politeknik Negeri Jember). Bahanbahan lain yang digunakan yaitu etanol $96 \%$ (teknis), metanol (p.a), etil asetat (p.a), nheksana (p.a), aquadest, DMSO, NA (Deben Diagnostic Ltd.), MHA (Himeidia), $\mathrm{NaCl}$ (PT. Smart- Lab Indonesia), blank disk, disk gentamisin $10 \mu \mathrm{g}, \mathrm{BaCl}_{2} 1 \%, \mathrm{H}_{2} \mathrm{SO}_{4} 1 \%$, biakan murni Staphylococcus aureus ATCC 6538 yang didapatkan dari Laboratorium Mikrobiologi dan Bioteknologi Fakultas Farmasi Universitas Jember.

\section{Pembuatan Ekstrak Etanol Rimpang Jahe}

Ekstraksi simplisia rimpang jahe dimaserasi 3 hari menggunakan pelarut etanol $96 \%$ (1:10). Remaserasi dilakukan sebanyak 2 kali. Semua maserat dikumpulkan dan diuapkan dengan rotary evaporator pada suhu $50^{\circ} \mathrm{C}$ hingga diperoleh ekstrak setengah kental, dilanjutkan penguapan di atas waterbath semalam.

\section{Fraksinasi Ekstrak Etanol Rimpang Jahe}

Ekstrak etanol rimpang jahe gajah, jahe emprit, dan jahe merah difraksinasi dengan metode partisi cair-cair dengan pelarut n-heksana dan etil asetat. Ekstrak kental ditimbang 10 gram, kemudian dilarutkan dengan etanol:air (1:9). Selanjutnya dimasukkan n-heksana $(1: 1) \mathrm{v} / \mathrm{v}$, difraksinasi menggunakan corong pisah 1015 menit (dilakukan 3 kali sampai frkasi yang diperoleh bening). Kemudian prosedur yang 
Tabel 1. Hasil fraksinasi ekstrak etanol 3 varietas jahe

\begin{tabular}{ccc}
\hline Varietas & \multicolumn{1}{c}{ Fraksi } & $\begin{array}{c}\text { Rendemen } \\
\text { Fraksi (\%) }\end{array}$ \\
\hline Jahe Emprit & Fraksi N-heksana & 26,67 \\
& Fraksi Etil Asetat & 18,06 \\
\multirow{2}{*}{ Jahe Gajah } & Fraksi N-heksana & 23,70 \\
& Fraksi Etil Asetat & 15,48 \\
Jahe Merah & Fraksi N-heksana & 27,40 \\
& Fraksi Etil Asetat & 10,65 \\
\hline
\end{tabular}

sama dilakukan dengan pealrut etil asetat (1:1 v/v). Kedua fraksi yang diperoleh diuapkan dengan rotavapor pada suhu $50^{\circ} \mathrm{C}$ hingga diperoleh fraksi setengah kental yang siap digunakan untuk uji.

\section{Pengujian Antibakteri}

Uji aktivitas antibakteri menggunakan metode difusi cakram. Kelompok uji yang disiapkan antara lain: ekstrak etanol dan fraksinya (n-heksana dan etil asetat) dari masing-masing jahe konsentrasi 5, 10, $20 \%$ $\mathrm{b} / \mathrm{v}$, gentamisin $10 \mu \mathrm{g}$ (kontrol positif), DMSO 10\% (kontrol negatif) (Winata, 2011). Bakteri uji disuspensi dalam $\mathrm{NaCl}$ fisiologis dan telah memenuhi standar Mc Farland 0,5. Sebanyak $100 \mu \mathrm{l}$ suspensi bakteri dipipet, diletakkan pada media MHA pada cawan petri, lalu di-spreader. Masing- masing sampel uji dipipet $100 \mu \mathrm{L}$, diteteskan pada kertas cakram pada plat tetes, kemudian didiamkan 24 jam dalam LAF. Masingmasing kertas cakram yang telah berisi sampel uji dipindahkan pada media di cawan petri, selanjutnya inkubasi 24 jam pada suhu $37^{\circ} \mathrm{C}$ (Purwantoro et al., 2010). Pengujian dilakukan 3 kali replikasi. Zona hambat diukur dengan bantuan jangka sorong.

\section{Analisis Data}

Hasil uji aktivitas antibakteri dianalisis dengan uji Kruskall Wallis dan analisis Mann-Whitney $(\alpha=0,05)$

\section{HASIL DAN PEMBAHASAN}

Ekstraksi rimpang tiga varietas jahe dilakukan menggunakan pelarut etanol $96 \%$ dengan perbandingan serbuk dan pelarut 1:10 (Novaldi et al., 2019). Ekstrak yang diperoleh dari hasil maserasi adalah jahe emprit $8,54 \%$, jahe gajah $11,86 \%$, dan jahe merah $11,28 \%$. Ekstrak kental selanjutnya difraksinasi partisi cair-cair menggunakan pelarut $\mathrm{n}$ - heksana dan etil asetat. Rendemen fraksi n-heksana dan etil asetat berturut-turut yaitu jahe emprit $26,67 \%$ dan $18,06 \%$; jahe gajah $23,70 \%$ dan $15,48 \%$; jahe merah 27,40\% dan 10,65\% ( Tabel 1).

Aktivitas antibakteri ekstrak etanol rimpang jahe dan fraksinya dapat dilihat pada Gambar 2.

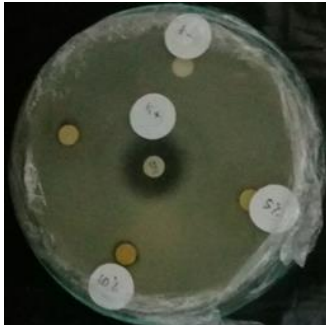

(a)

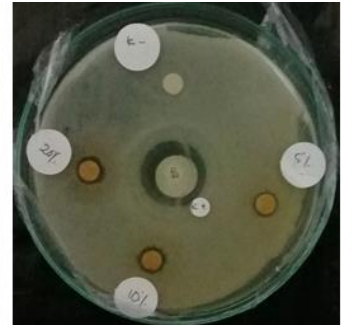

(b)

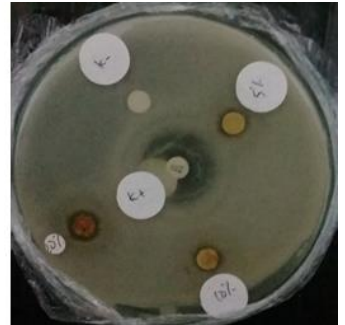

(c)

Gambar 2. Zona Hambat Ekstrak Etanol Jahe Emprit (A), Jahe Merah (B) dan Jahe Gajah (C) Terhadap S.aureus pada seri konsentrasi uji 5, 10, dan 20\% (b/v); Gentamisin $10 \mu \mathrm{g}$; DMSO $10 \%$ 
Tabel 2. Hasil Analisis Statistik Uji Antibakteri Ekstrak Etanol, dan Fraksinya Dari Rimpang Jahe Antar Konsentrasi yang Berbeda

\begin{tabular}{|c|c|c|c|}
\hline Varietas & Jenis Pelarut & Konsentrasi $(\%)$ & $\begin{array}{c}\text { Diameter Hambat }(\mathrm{mm}) \\
\text { mean } \pm \text { SD }\end{array}$ \\
\hline \multirow[t]{9}{*}{ Jahe Emprit } & \multirow[t]{3}{*}{ Etanol } & 5 & $7,84 \pm 0,14^{\mathrm{a}}$ \\
\hline & & 10 & $8,30 \pm 0,07^{\mathrm{b}}$ \\
\hline & & 20 & $8,41 \pm 0,09^{b}$ \\
\hline & \multirow[t]{3}{*}{ N-heksana } & 5 & $8,51 \pm 0,06^{a}$ \\
\hline & & 10 & $9,690 \pm 0,17^{b}$ \\
\hline & & 20 & $9,80 \pm 0,11^{\mathrm{b}}$ \\
\hline & \multirow[t]{3}{*}{ Etil Asetat } & 5 & $6,80 \pm 0,08^{a}$ \\
\hline & & 10 & $8,32 \pm 0,12^{\mathrm{b}}$ \\
\hline & & 20 & $8,66 \pm 0,16^{\mathrm{c}}$ \\
\hline \multirow[t]{9}{*}{ Jahe Gajah } & \multirow[t]{3}{*}{ Etanol } & 5 & $7,74 \pm 0,08^{a}$ \\
\hline & & 10 & $7,76 \pm 0,01^{b}$ \\
\hline & & 20 & $8,20 \pm 0,05^{\mathrm{c}}$ \\
\hline & \multirow[t]{3}{*}{ N-heksana } & 5 & $8,12 \pm 0,05^{\mathrm{a}}$ \\
\hline & & 10 & $9,34 \pm 0,06^{\mathrm{b}}$ \\
\hline & & 20 & $9,78 \pm 0,17^{\mathrm{c}}$ \\
\hline & \multirow[t]{3}{*}{ Etil Asetat } & 5 & $7,74 \pm 0,15^{a}$ \\
\hline & & 10 & $8,18 \pm 0,05^{\mathrm{b}}$ \\
\hline & & 20 & $8,51 \pm 0,08^{c}$ \\
\hline \multirow[t]{9}{*}{ Jahe Merah } & \multirow[t]{3}{*}{ Etanol } & 5 & $7,93 \pm 0,14^{\mathrm{a}}$ \\
\hline & & 10 & $8,19 \pm 0,04^{\mathrm{b}}$ \\
\hline & & 20 & $9,22 \pm 0,12^{\mathrm{c}}$ \\
\hline & \multirow[t]{3}{*}{ N-heksana } & 5 & $8,36 \pm 0,06^{\mathrm{a}}$ \\
\hline & & 10 & $8,75 \pm 0,02^{\mathrm{b}}$ \\
\hline & & 20 & $9,90 \pm 0,07^{\mathrm{c}}$ \\
\hline & \multirow[t]{3}{*}{ Etil Asetat } & 5 & $7,57 \pm 0,14^{\mathrm{a}}$ \\
\hline & & 10 & $7,89 \pm 0,04^{b}$ \\
\hline & & 20 & $8,51 \pm 0,15^{\mathrm{c}}$ \\
\hline
\end{tabular}

Pada Tabel 2 dapat dilihat data diameter zona hambat untuk semua sampel uji. Dari data hasil penelitian, pada konsentrasi 5, 10, dan $20 \% \mathrm{~b} / \mathrm{v}$, semua sampel uji memiliki aktivitas penghambatan pertumbuhan bakteri S. aureus.

Secara umum, diameter zona hambat baik pada ekstrak etanol rimpang jahe maupun fraksinya mengalami peningkatan dengan semakin bertambahnya konsentrasi. Namun ekstrak etanol jahe emprit 10 dan $20 \%$ b/v memiliki aktivitas antibakteri yang tidak berbeda signifikan, begitu juga pada fraksi nheksananya. Faktor yang diduga mempengaruhi terbentuknya zona bening pada media agar antara lain adanya perbedaan kecepatan berdifusi ekstrak pada agar, serta perbedaan jenis senyawa ekstrak dan konsentrasi senyawa dalam ekstrak itu sendiri.

Analisis data selanjutnya dilakukan pada sampel uji konsentrasi $20 \%$ b/v, yang dianggap memiliki aktivitas antibakteri optimal dalam penelitian ini. Urutan aktivitas antibakteri ekstrak etanol rimpang jahe ketiga varietas terhadap $S$. aureus pada konsentrasi uji $20 \%$ dari yang terbesar ke terkecil adalah jahe emprit: fraksi n- heksana, ekstrak etanol dan fraksi etil asetat ; jahe gajah: fraksi nheksana, fraksi etil asetat, ekstrak etanol; jahe merah: fraksi n-heksana, ekstrak etanol, fraksi etil asetat. Fraksi n-heksana dari masing- 
Tabel 3. Hasil Analisis Statistika Uji Antibakteri Ekstrak Etanol, dan Fraksinya Dari Rimpang Jahe Pada Konsentrasi $20 \%$

\begin{tabular}{ccc}
\hline Varietas & Jenis Pelarut & $\begin{array}{c}\text { Diameter Hambat (mm) } \\
\text { rerata } \pm \text { SD }\end{array}$ \\
\hline Jahe Emprit & Etanol & $8,41 \pm 0,09^{\mathrm{a}, 1}$ \\
& N-heksana & $9,80 \pm 0,11^{\mathrm{b}, 1}$ \\
& Etil Asetat & $8,66 \pm 0,16^{\mathrm{a}, 1}$ \\
\hline Jahe Gajah & Etanol & $8,20 \pm 0,05^{\mathrm{a}, 2}$ \\
& N-heksana & $9,78 \pm 0,17^{\mathrm{b}, 1}$ \\
& Etil Asetat & $8,51 \pm 0,08^{\mathrm{c}, 1}$ \\
\hline Jahe Merah & Etanol & $9,22 \pm 0,12^{\mathrm{a}, 3}$ \\
& N-heksana & $9,90 \pm 0,07^{\mathrm{b}, 1}$ \\
& Etil Asetat & $8,51 \pm 0,15^{\mathrm{c}, 1}$ \\
\hline
\end{tabular}

Notasi $\left({ }^{\mathrm{a}, \mathrm{b}, \mathrm{c}}\right)$ menunjukkan perbedaan antar jenis pelarut pada varietas jahe yang sama

Notasi $(1,2,3)$ menunjukkan perbedaan antar varietas jahe pada jenis pelarut yang sama

masing varietas jahe memiliki aktivitas antibakteri terbesar dibandingkan ekstrak etanol dan fraksi etil asetat, dengan nilai diameter zona hambat: jahe emprit $9,80 \mathrm{~mm}$; jahe gajah 9,78; dan jahe merah 9,90 mm. Namun jika dibandingkan antar varietas jahe, fraksi n-heksana $20 \% \mathrm{~b} / \mathrm{v}$ memiliki aktivitas antibakteri yang tidak berbeda signifikan, begitu pula dengan fraksi etil asetatnya. Sehingga perbedaan varietas jahe hanya mempengaruhi aktivitas antibakteri pada kelompok ekstrak etanol saja. Aktivitas antibakteri ekstrak etanol dari yang terbesar ke terkecil yaitu jahe merah 9,22 mm; jahe emprit 8,41 $\mathrm{mm}$, dan jahe gajah $8,20 \mathrm{~mm}$ (Tabel 3).

Perbedaan pelarut akan mempengaruhi senyawa kimia yang terekstraksi/ terfraksinasi. Pelarut etanol dapat menarik hampir semua kandungan senyawa kimia sampel. yaitu minyak atsiri, tannin, saponin, alkaloid, flavonoid, fenol (Ojayi dan Omomogiowawi, 2018). N- heksana yang merupakan pelarut nonpolar akan menarik senyawa-senyawa non polar pada ekstrak etanol. N-heksana dapat mengekstraksi minyak atsiri yang juga bersifat nonpolar. Sedangkan pelarut etil asetat adalah pelarut semipolar yang akan menarik senyawa yang bersifat semipolar yang tidak terekstraksi oleh n-heksana. Ekstrak etil asetat jahe merah positif mengandung terpenoid, flavonoid dan alkaloid (Purbaya et al., 2018).
Kandungan senyawa pada jahe yang utama adalah minyak astsiri, golongan terpenoid yang telah terbukti sebagai antibakteri. Selain minyak atsiri, jahe juga mengandung golongan saponin, flavonoid, dan polifenol yang juga diduga memiliki aktivitas penghambatan pertumbuhan bakteri (Munda et al.., 2018). Senyawa yang terkandung pada minyak atsiri jahe antara lain lain $\alpha$-pinena, kamfena, kariofilena, $\beta$-pinena, $\alpha$-farnesena, sineol, dl-kamfor, isokariofilena, kariofilenaoksida, dan germakron (Sari dan Nasir, 2013).

Mekanisme kerja minyak atsiri sebagai antibakteri adalah kemampuan minyak atsiri untuk mengganggu dinding sel dan membran sitoplasma, yang mengarah pada lisis dan kebocoran senyawa intraseluler (Romero et al., 2015). Mekanisme antibakteri saponin adalah dengan menurunkan tegangan permukaan sel sehingga dapat menyebabkan kebocoran sel. Sedangkan flavonoid dengan mekanisme antibakteri sebagai berikut: inhibisi pembentukan asam nukleat, inhibisi fungsi membran sel, inhibisi metabolisme energi, inhibisi perlekatan dan pembentukan biofilm, inhibisi porin pada membran sel, perubahan permeabilitas membran, dan atenuasi patogenisitas, membentuk komplek fenol-protein yang dapat menyebabkan penggumpalan protein sehingga sel pecah (Xie et al., 2015). 
Ojayi dan Omomogiowawi (2018), melaporkan bahwa ekstrak etanol jahe konsentrasi 0,2;0,4 dan $6 \mathrm{~g} / \mathrm{mL}$ mampu menghambat pertumbuhan $S$. aureus dengan diameter hambat berturut-turut 1,0; 5,0; dan 4,0 $\mathrm{mm}$. Pada penelitian yang dilakukan oleh Nurjanah dan Fathia (2017) ekstrak heksana, etil asetat, dan etanol jahe gajah $100 \mathrm{mg} / \mathrm{mL}$ mampu menghambat bakteri $S$. aureus sebesar 5,0; 5,7; 1,3 mm. Daya hambat ekstrak jahe dan fraksinya dari ketiga rimpang jahe pada penelitian ini lebih besar (diameter zona hambat 6,8-9,9 $\mathrm{mm}$ ) dibandingkan dengan kedua penelitian tersebut. Perbedaan besarnya aktivitas antibakteri diduga disebabkan perbedaan kandungan metabolit sekunder jahe antar daerah. Perbedaan kondisi wilayah tanam, seperti kondisi tanah, kualitas bibit jahe, penanganan pascapanen, dan metode budidaya dapat berpengaruh pada kandungan senyawa aktif jahe (Chmit et al., 2014).

Fraksi n-heksana dari ketiga varietas jahe memiliki aktivitas antibakteri terbesar diduga karena kandungan minyak atsiri yang berfungsi sebagai agen antibakteri. Senyawa utama dalam jahe adalah minyak atsiri jahe telah diidentifikasi oleh Elbaroty et al., (2010) menggunakan bioautografi TLC yaitu $\beta$ sesquiphellandren, caryophyllen, dan zingiberen.

Perbedaan varietas jahe hanya mempengaruhi aktivitas antibakteri pada kelompok ekstrak etanol. Sedangkan aktivitas penghambatan pertumbuhan bakteri dari fraksi n-heksana dan etil asetat antar varietas jahe tidak berbeda signifikan. Ekstrak etanol dari jahe merah memiliki aktivitas lebih besar daripada kedua varietas lainnya diduga disebabkan oleh jahe merah memiliki kadar minyak atsiri yang lebih besar dibandingkan kedua varietas lainnya. Kandungan minyak atsiri jahe merah $0,887 \%$, sedangkan jahe gajah 0,454\% dan jahe emprit 0,675\% (Susihono, 2011).

\section{KESIMPULAN}

Berdasarkan hasil penelitian yang dilakukan, dapat disimpulkan bahwa ekstrak etanol rimpang jahe dan fraksinya dari tiga varietas jahe memiliki aktivitas antibakteri terhadap S.aureus pada konsentrasi 5, 10, dan $20 \% \mathrm{~b} / \mathrm{v}$, dengan naiknya konsentrasi akan meningkatkan daya hambatnya. Pada konsentrasi $20 \%$ b/v dari semua sampel, yang memiliki daya hambat paling besar adalah fraksi n-heksana. Aktivitas antibakteri fraksi n-heksana dan etil asetat dipengaruhi oleh perbedaan varietas jahe, tetapi tidak pada ekstrak etanol.

\section{SARAN}

Diperlukan penelitian mengenai skrining fitokimia ekstrak dan fraksi rimpang jahe untuk memastikan kandungan senyawa kimianya dan aktivitas antibakteri dari rimpang tiga varietas jahe terhadap bakteri lain.

\section{UCAPAN TERIMAKASIH}

Penelitian ini didanai oleh DIPA UNEJ Tahun 2018.

\section{Daftar Pustaka}

Ajayi, A.O. and Omomagiowawi, I.E. 2014. Antimicrobial activities and phytochemical analysis of Zingiber officinale (Ginger) on Staphylococcus aureus and Streptococcus species. Mitteilungen Klosterneuburg. Vol. 64: 1-17.

Chmit, M., Kanaan, H., Habib, J., Abbas, M., Mcheik, A., Chokr, A. 2014. Antibacterial and antibiofilm, activities of polysaccharides, essentiali oil, and fatty oil extracted from Laurus nobilis growing in Lebanon. Asean Pasific Journal of Tropical Medicine. 546-552. 
Daryono, E.D.. 2009. Minyak Oleoresin dari Jahe Menggunakan Proses Ekstraksi dengan Pelarut Etanol. "Ekstrak" Jurnal Fundamental dan Aplikasi Teknik Kimia. Vol. 4 (3): 105109.

El-Baroty, G.S., El-Baky, H.H.A., Farag, R.S., Saleh, M.A. 2010. Characterization of antioxidant and antimicrobial compounds of cinnamon and ginger essential oils. Afr J Bio Res 4(6): 167-174.

Mishra, A. K., Yadav P., and Mishra P. 2016. A systemic review on staphylococcal scalded skin syndrome: a rare and critical disease of neonates. The Open Microbiology Journal. 10(1):150-159.

Novaldi, P., Hardi, J., Hardi, Y. 2019. Mikroenkapsulasi Ekstrak Ampas Jahe Merah Dari Hasil Pemisahan Minyak Jahe Merah. Kovalen: Jurnal Riset Kimia. Vol. 5(1): 17-23.

Nurjanah, S. dan Fathia, S. 2017. Aktivitas Antimikroba Ekstrak Jahe Kering Beku Terhadap Beberapa Bakteri Patogen. Jurnal Mutu Pangan. Vol. 4(1): 8-15.

Purbaya, S., Aisyah, LS., Jasmansyah, Arianti, W E. 2018. Aktivitas Antibakteri Ekstrak Etil Asetat Jahe Merah (Zingiber officinale Roscoe var. sunti) Terhadap Bakteri Staphylococcus aureus dan Escherichia coli. Jurnal Kartika Kimia. 1 (1):29-34.

Purwantoro, R.S., Hartutiningsih, M., Siregar, Sudarmono dan Praptiwi 2010. Uji Antibakteri Lasianthus Sebagai Tumbuhan Berkhasiat Obat Dan Upaya Perbanyakannya. Buletin Kebun Raya. 13(2): 86-93.

Rambiko, S.C., Fatimawali., dan Widdhi B., 2016, Uji Sensitivitas Bakteri Penyebab Infeksi Nosokomial Saluran Kemih Akibat Penggunaan Kateter Terhadap Antibiotik Ampicillin, Amoxicillin dan Ciprofloxacin Di RSUP Prof. Dr. R.D Kandou Manado, Pharmacon Jurnal Ilmiah Farmasi, Vol. 5 (1).

Romero, J.C.L., Rios, H. G., Borges, A., Simoes, M. 2015. Antibacterial Effects and Mode of Action of Selected Essential Oils Components against Escherichia coli and Staphylococcus aureus. Evidence-Based Complementary and Alternative Medicine.Vol. 2015.

Sari, K., Periadnadi dan Nasril Nasir. 2013. Uji Antimikroba Ekstrak Segar JaheJahean (Zingiberaceae) Terhadap Staphylococcus aureus, Escherichia coli dan Candida albicans. Jurnal Biologi Universitas Andalas.

Setyawan A. D., Wiryanto, Suranto, Bermawie, N.2014. Variation in isozymic pattern of germplasm from three of ginger (Zingiber officinale) varieties. Nusantara Bioscience. 6(1):86- 93 .

Susihono, W., 2011. Kualitas Rendemen Jahe Asal Indonesia Sebagai Dasar KelayakanJual Ginger Oil Pada Pasar International. Widyariset. Vol. 14 (3): 579-588.

Munda, S., Dutta, S., Haldar,S., dan Lal, M .2018. Chemical Analysis and Therapeutic Uses of Ginger (Zingiber officinale Rosc.) Essential Oil: A Review. Journal of Essential Oil Bearing Plants.Vol. 21(4): 994-1002. 
Winata, L. C. W. P. 2011. Uji Aktivitas Antimikroba Ekstrak Etanol Herba Benalu Mangga (Dendrophthoe petandra L. Miq.) Terhadap Bakteri Staphylococcus aureus ATCC 6538 Dan Escherichia coli ATCC 11229 Secara Invitro. http://eprints.ums.ac.id/14883/ [Diakses pada December 23, 2019].

Xie, Y., Yang, W., Tang, F., Chen, X., dan Ren, L. 2015. Antibacterial Activities of Flavonids: Structure-Activity Relationship and Mechanism. Curr Med Chem. Vol. 22(1):132-49. 